\title{
On the Registration of Pseudo-Anglicisms in Modern Russian Lexicography
}

\author{
SZABOLCS JANURIK \\ ELTE BTK Orosz Nyelvi és Irodalmi Tanszék, H-1088 Budapest, Múzeum krt. 4/D. \\ Department of Russian Language and Literature, Faculty of Humanities, Eötvös Loránd University \\ E-mail: janurik@yahoo.com
}

(Received: 31 March 2018; accepted: 27 May 2018)

\begin{abstract}
The aim of the present paper is to analyze how pseudo-English loanwords are registered in modern lexicography. This is a rather new and quickly developing research field in European linguistics, however, in Russia, it has received hardly any attention so far. These lexical items are usually treated as real English borrowings in Russian dictionaries, despite the fact that they are not used in the source language in the form they are presented by lexicographers. It is also pointed out in the paper that some pseudo-Anglicisms have been transferred into Russian through one of the main intermediary languages of Europe (French or German).

Keywords: language contact, borrowing process, English loanwords, pseudo-Anglicisms, Russian lexicography
\end{abstract}

\section{Introduction}

The term pseudo-Anglicism describes a phenomenon that occurs "when the receptor language uses lexical elements of the source language to create a neologism in the receptor language that is unknown in the source language" (ONYsKo 2007: 52). According to another definition, semantic factors should also be considered: a pseudo-Anglicism is "a word or idiom that is recognizably English in its form (spelling, pronunciation, morphology, or at least one of the three), but is accepted as an item in the vocabulary of the receptor language even though it does not exist or is used with a conspicuously different meaning in English" (FURIASSI 2010: 34). A third approach suggests that pseudo-Anglicisms are "coinages that resemble words from the prestige language, English, but which would not be recognized or understood by monolingual English native speakers, and which, if translated from a source text into English by a native speaker, would be substituted by a genuine English word" (Furiassi-GotTLIEB 2015: 16-17).

This phenomenon of language contact has so far received only fragmentary attention in Russian linguistics. In a dictionary on the theory of borrowing, Jelena Marinova labels a pseudo-Anglicism as a word which is created in Russian from English stems and affixes and which is similar to an Anglicism in terms of its formal features (Маринова 2013: 168). As defined by Ljubov' Nefedova, pseudoloans are words derived from elements of a foreign language, thus, they are the products of Russian word formation (НЕФЕДОвА 2013: 121). A broader definition 
is found in a recent study on English loanwords in Russian: pseudo-Anglicisms are either 1) lexical units borrowed from English into another language, which have a meaning differing from the source language, and which are used in contexts and situations in which they would never appear in English; or 2) Russian formations created by combining English morphemes or imitating the phonetic shape of English words (Дьяков 2012: 115).

In the present study, 25 pseudo-Anglicisms will be analyzed with regard to their registration in modern Russian lexicography. As it will be pointed out, most of these lexical items are treated inadequately in Russian dictionaries.

\section{The classification of pseudo-Anglicisms}

2.1. The well-known tripartite typology offered by Broder Carstensen in 1980 is used in several recent studies on pseudo-Anglicisms (FuRIASSI-GotTLIEB 2015: $27,241)$. On the basis of this classification, the following types of pseudo-loans can be distinguished:

1) lexical pseudo-loans, i.e. combinations of English lexical elements to form a word which does not exist in English;

2) morphological pseudo-loans, i.e. reduction of a compound or elision of an element in the English expression;

3) semantic pseudo-loans, i.e. attribution of a new meaning to an already existing English word (PULCINI 2002: 163).

2.2. Some researchers, however, include only the first type in the notion of pseudo-Anglicisms. As argued by Alexander Onysko, the division of pseudo-loans into these categories blurs the difference between the semantic and morphological adaptation of Anglicisms in the recipient language and the creation of pseudoAnglicisms as lexical units irrespective of an English model (ONYSKO 2007: 53). Another prominent representative of this "hardcore" approach is John Humbley, who suggests the term allogenisms for "true pseudo-loans", i.e. recombinations of English morphemes in other languages (HuMBLEY 2015).

2.3. The most detailed classification of pseudo-Anglicisms has been offered by Cristiano Furiassi, who put forward eight categories:

1) autonomous compounds, formed with two lexical elements that can be separately found in English, whose compound form is a genuine recipient-language product (such compound words are not used in English);

2) autonomous derivatives, composed of an English free morpheme (lexical element) and an English bound morpheme (grammatical element);

3) compound ellipses, i.e. the reducing of English compounds by eliminating an entire lexical item;

4) clippings, i.e. the shortening of English words by deleting a suffix;

5) semantic shifts (metaphoric, metonymic, or meronymic shifts);

6) eponyms, 7) toponyms, or 8) trademarks used in a generic sense (FURIASSI 2010: 38-52). 


\section{Pseudo-Anglicisms in Russian lexicography}

Applying Furiassi's classification in this study for the 25 pseudo-Anglicisms used in present-day Russian, the following types can be determined:

1) compounds: бизнес-леди (for Eng. businesswoman), фейс-контроль (for a common practice at Russian night clubs: 'checking whether a person looks appropriate'), won-myp (for 'an organized tour to a foreign country for shopping'), лонгселлер (for Eng. long-time bestseller);

2) derivatives: баннермейкер (for Eng. banner designer), брендмейкер (for Eng. brand creator), гейммейкер (for Eng. game developer), клипмейкер (for Eng. music video director), татумейкер (for Eng. tattoo artist), трендмейкер (for Eng. trendsetter), сейфинг (for Eng. providing safe deposit boxes), автогол (for Eng. own goal), aвтостоn (for Eng. hitchhiking), антистеплер (for Eng. staple remover);

3) ellipses: кемпинг (for Eng. camping site), паркинг (for Eng. parking lot), смокинг (for Eng. smoking jacket), холдинг (for Eng. holding company), боди (for Eng. bodysuit), maйм (for Eng. half-[time]);

4) clippings: хеппи-энд (for Eng. happy ending);

5) semantic shifts: киллер (for Eng. hit man or contract killer), олдтаймер (for Eng. classic car or vintage car), шоу-вумен (for Eng. female TV presenter);

6) trademarks: скотч (for Eng. adhesive tape).

3.1. Comparing the lexicographic registration of the three compounds consisting of English elements but created in the Russian language, we can find significant differences in their treatment in various dictionaries.

In a number of lexicographic works, there is no information at all concerning the etymology of the Russian neologism бизнес-леди (СКляРЕВСКАя 1998: 86, СКЛЯРЕВСКАЯ 2006: 125, СКЛЯРЕВСКАЯ-ВАУЛИНА 2004: 59, ССИС 2009: 32). Even in dictionaries of foreign words, reference to the source of this expression is often omitted. Only the authors of the НСИС $(2003: 99,2008: 129)$ claim that it was derived in Russian from earlier English loans бизнес- and леди. Though not declared a pseudo-Anglicism clearly, it might be an implicit indication in Russian lexicography that there is something problematic in the etymologization of this lexical item as a real borrowing. Only two dictionaries ascribe it to the supposed English form business lady (ГРигоРЕнКо 2009: 47, Дьяков 2010).

On the contrary, there seems to be widespread agreement among Russian lexicographers about the existence of the compound face control in English (HСИС 2003: 679, НСИС 2008: 896, СКЛЯРЕВСКАЯ 2006: 1042, ШАГАЛОВА 2009: 789, ШАГАЛОВА 2011: 618-619, ШАГАЛОВА 2017: 479-480). However, this phrase is not attested in any of the major English-language dictionaries (OED or MerriamWebster). It is also characteristic that in a newspaper article recently published in the section "BBC Culture" entitled "The foreign words that seem like English but aren't", exactly this word is mentioned as an instance of pseudo-Anglicisms in Russian: "In Moscow, would-be clubbers must first make it past feyskontrol ('face 
control'), to ensure that only the beautiful people come in" (ANDERSON 2016). Nevertheless, there are just two Russian dictionaries that get along without this unEnglish "phantom" expression and confine themselves to translating the constructing elements of the compound into Russian: face 'лицо' + control 'проверка' (КомЛЕв 1999: 375, ИСАЗ 2016: 124). Тhe ССИС (2009: 427), again, lacks any explanation of its possible origin.

The case of the Russian innovation uon-myp is even more intriguing. In their etymological sections, about half of the lexicographic works give non-existing English forms shop tour (ШАГАЛОВА 2009: 886-887, ШАГАЛОВА 2017: 541-542), shoptour (ИСАЗ 2016: 139), and shopping tour (СкЛЯРЕВСКАЯ 1998: 678-679, СкляРЕВСКАЯ 2006: 1082, ССИС 2009: 454). The other half of dictionaries, however, indicate only the English components from which the neologism is made up, without specifying whether the compound was coined in the source language or in the recipient language: shop 'магазин' + tour 'поездка' (Комлев 1995: 134, Комлев 1999: 411, Крысин 2000: 800, Крысин 2009: 308, ССИС 2002: 956, НСИС 2003: 739, НСИС 2008: 978, СТС 2001: 939).

The registration of the compound word лонгселлер in Russian lexicography raises further questions. On the basis of dictionary data, one could conclude that this is a real Anglicism in Russian, corresponding to English longseller (КомлЕВ 1999: 209, НСИС 2003: 365, НСИС 2008: 480, ССИС 2009: 224, ШАГАЛОВА 2009: 370, ШАГАЛОВА 2011: 308, ШАГАЛОВА 2017: 237). This lexical item is indeed included in the Dictionary of European Anglicisms, where its entry is followed by an asterisk, which means that is not an English word (DEA 2001: 189). The term Longseller is a pseudo-Anglicism created in the German language denoting 'something that sells well for a long time' (ONYsKo 2007: 54). Its presence in German is confirmed by the online version of the Duden dictionary. ${ }^{1}$ At the same time, no such word is recorded in English lexicography. Thus, it seems most likely that Russian лонгселлер, instead of being a direct loanword from English as suggested by all Russian dictionaries, is in fact the outcome of borrowing the German pseudo-Anglicism Longseller.

3.2. One of the most productive combining elements applied in many pseudoEnglish formations in Russian is the compound -мейкер, already aspiring for the status of a suffixoid due to its frequent use over the last two or three decades. It is also present in real Anglicisms in Russian: e.g. имиджмейкер (< Eng. imagemaker), кингмейкер (< Eng. kingmaker), маркетмейкер (< Eng. market maker), and хитмейкер (< Eng. hitmaker).

Within this group of lexical innovations, the most widespread neologism is клипмейкер. Apart from Russian dictionaries, it is also registered in the Dictionary of European Anglicisms, marked by an asterisk indicating its non-English origin (DEA 2001: 61). In spite of this fact as well as the absence of this lexical item in English-language dictionaries, the majority of Russian lexicographic works

\footnotetext{
${ }^{1}$ https://www.duden.de/rechtschreibung/Longseller
} 
consider this word a real loan, presenting its supposed etymon in three various orthographic forms: clipmaker (ССИС 2002: 340-341, ССИС 2009: 159, КРысин 2009: 124, КРЫСИН 2012: 148, ИСАЗ 2016: 51), clip maker (ГРиГОРЕНКО 2009: 191, ШАГАЛОВА 2009: 308, ШАГАЛОВА 2017: 203), clip-maker (КРЫСин 2000: 851, НСИС 2003: 290, НСИС 2008: 382). A second way of presenting etymological information is chosen only by a few authors: clip 'клип' + maker 'создатель' (КомЛЕв 1995: 57, КомЛЕв 1999: 173, ВАСюКОвА 1999: 296, СТС 2001: 273, СкЛЯРЕВСКАЯ-ВАУлИНА 2004: 107). However, it does not help to solve the problem of the lexicographic registration of this pseudo-Anglicism either, because it is not clear if the act of the derivation took place in English or in Russian. Yet another kind of decision is made in СкляРеВСКАЯ 2006: 460, where the origin of клипмейкер is not clarified, possibly implying that this lexical item has emerged as the result of Russian word formation processes (otherwise, Anglicisms are consequently provided with their English counterparts in this dictionary).

The rest of pseudo-English derivatives that includes the component -мейкер (баннермейкер, брендмейкер, гейммейкер, трендмейкер) is also listed together with their "phantom"-English form: banner maker (ГРигОРЕнко 2009: 38), brand maker (ГРИГОРЕНКО 2009: 66, ШАГАЛОВА 2009: 108, ШАГАЛОВА 2017: 81-82), game maker (ГРИГОРЕнКо 2009: 98), and trendmaker (ИСАЗ 2016: 117). The only exclusion is татумейкер, which is dealt with in various ways in the two dictionaries that register it: as going back to English tattoo maker (ГРигоренко 2009: 401-402) and as composed of the earlier borrowing mamy and English maker (НСИС 2003: 627, НСИС 2008: 828).

The English suffix -ing sometimes takes part in the creation of Russian derivatives, formally corresponding to a lexical item in English but, at the same time, semantically diverging from it. The financial term сейфинг 'providing safe deposit boxes' as a cross-lingual homonym of English safing 'the action of securing or making safe' (OED) since it was derived from the earlier loan ceŭ $\phi$ 'a strong fireproof cabinet with a complex lock, used for the storage of valuables (OED), and not from the adjective safe 'not exposed to danger' (OED), like the English noun. In this sense, сейфинг may also be viewed as a pseudo-Anglicism in Russian.

In contrast with the previous examples, the remaining pseudo-English derivatives (автогол, автостоп, and антистеплер) do not have structurally similar counterparts in English. They are created by means of prefixation in the recipient languages. According to the Dictionary of European Anglicisms, Russian aвmocmon is based on the French pseudo-Anglicism auto-stop and it was transmitted from French into Russian at the end of the 20th century (DEA 2001: 10). This etymologization is quite plausible, regarding the fact that the French word emerged definitely not later than the $1950 \mathrm{~s}$, even though the Russian form aвmocmon is in fact attested in lexicography much earlier than stated in the source mentioned above (cf. HC3-60, a dictionary covering neologisms in Russian from the 1960s).

The football term автогол cannot be claimed a Russian derivative either. It is recorded quite rarely in Russian lexicographic works, and the few dictionaries that do include this word either say nothing about its origin (СкляРевсКАЯ 2006: 35) 
or simply state that it is composed of the Greek prefix auto- and the English noun goal (КомЛЕВ 1999: 9, ССИС 2009: 8). The term autogoal is frequently used in French, where it may be either a loanword based on German Eigentor or a loan from Italian autogoal (Humbley 2015: 43). The last one is included in the dictionary of pseudo-Anglicisms in Italian (FURIASSI 2010: 140).

Apart from an entry in the Russian orthographic dictionary (POC 2012: 20), the neologism антистеплер has had no lexicographic registration so far. In a recent study on new English borrowings in Russian, this word is characterized as an instance of pseudo-Anglicisms (Дьяков 2012: 115). It seems quite plausible that this term was coined in Russian on the basis of a word formation model (by adding the prefix anti- or $a н m u$-) which is very productive in both the source and the recipient language.

3.3. The three classical examples of an ellipsis of English compounds in European languages (camping, parking, and smoking) are found in Russian as well.

These elliptical forms, however, are treated quite differently in various Russian lexicographic works. In the case of кемпинг and паркинг, the abbreviated pseudo-English terms (camping and parking) are mentioned in terms of etymons in all of the dictionaries, while for смокинг, the original compound smoking jacket is given (which is no longer in active use in present-day English). Cross-linguistically diverging semantic features, i.e. the English nouns camping and parking may denote only a process, whereas Russian кемпинг and паркинг can refer exclusively to a place, are totally ignored. Also, a diachronic approach to the noun смокинг can reveal that it is now "a fossilized loanword" (DEA 2001: 292) maintained in the recipient language after becoming an archaism in the source language, being replaced by dinner jacket in British English and tuxedo in American English. According to the Dictionary of European Anglicisms, all these three compound ellipses spread over continental Europe through French mediation (DEA 2001: 47, 226, 292), and despite their English-looking forms, кемпинг, паркинг, and смокинг also seem to be indirect borrowings transmitted to Russian via French rather than direct loans from English.

The equivalent of the Russian sports term тайм in English is half 'either of the two equal periods that together make up the playing time of some games' (Merriam-Webster). Both of these words go back to the English compound halftime, though they were shortened diversely: the first component was kept in English, and the second element took over the meaning of the whole expression in Russian. (Interestingly, German Halbzeit and Hungarian félidó are calques based on the original English compound.) In Russian lexicography, only the basic meaning of the English noun time 'время' is indicated, and the ellipsis of the original compound word is disregarded.

Likewise, recent borrowings боди and холдинг are described in all Russian dictionaries as words corresponding to English nouns body and holding. Nevertheless, the semantics of these pseudo-Anglicisms in Russian correlates much more with the sense of the original English compounds bodysuit and holding company. 
3.4. Probably the best-known instance of cross-linguistic clipping in European languages in the pseudo-Anglicism happy end standing for English happy ending. In Russian, the shortened form хеппи-энд is used as well. Just like in the case of other mediated non-English formations, the morphological change (the elimination of the suffix -ing) took place neither in the source language nor in the recipient language but in another European language (French or German) functioning as an intermediary one. Some of these pseudo-Anglicisms have even reached the status of internationalisms: e.g. autostop, smoking, and happy end are found in several European and non-European languages (FURIASSI 2010: 66-67).

3.5. There is a special group of pseudo-English loan containing words which have formal equivalents in the source language but their meaning is altered in the recipient language to the extent that it departs significantly from the English original. These semantic shifts may involve a process of meaning extension (widening) or meaning restriction (narrowing).

For example, the Russian neologism шоу-вумен denotes 'a female presenter of a television show'. Apart from the academic orthographic dictionary (POC 2012: 835 ), this word is registered in just two other lexicographic works (ГРигОРенко 2009: 485, HC3-90/3: 1306-1307), both of which relate it to English show-woman. As attested by the Oxford English Dictionary, this noun does exist in the source language, though its meaning is somewhat different: 'a woman who produces or presents shows as an occupation, especially one who works at a circus, fair, or other travelling show' (OED).

Another instance of semantic narrowing is киллер, a word of English origin enjoying great popularity in Russian, especially in the 1990s. As the etymon of this borrowed lexical item, the English noun killer is indicated in almost all Russian dictionaries, despite the fact that in the recipient language, киллер designates 'a person who is paid to kill someone', a meaning that is not present in the source language. A 'professional assassin' is usually called a hitman (OED) or a hit man (Merriam-Webster) in English, whereas the noun killer is used in a more general sense: 'a person or thing that kills' (OED). The diverging semantic features of Russian киллер and English killer, however, might be explained in a different way, too. A clue to this is given in the only Russian dictionary which interprets the origin of киллер independently of all other lexicographic works, presenting the English compound contract killer as its possible source (ИСАЗ 2016: 51). This word is indeed recorded in the Collins English Dictionary as a British term for 'a person hired to commit a murder' (CED). Thus, instead of being an example of semantic shift, the pseudo-Anglicism киллер can be classified as the outcome of an ellipsis of the English compound contract killer as well. It is also quite plausible that the shortening of the original expression took place in the German language, where the noun Killer is used in the same sense as in Russian. ${ }^{2}$ Consequently, Russian киллер may be either the result of semantic narrowing (not all murderers, only

\footnotetext{
${ }^{2}$ https://www.duden.de/rechtschreibung/Killer
} 
the professional ones) or that of borrowing the German elliptical pseudo-English form Killer. In the first case, the modification in the meaning of Russian киллер as compared to English killer could be treated as a process of semantic adaptation involving a real Anglicism if we exclude semantic shifts from the notion of pseudoborrowings and label them "real though modified loans" whose semantic range has evolved differently (cf. HUMBLEY 2015: 38).

The Russian neologism олдтаймер denoting 'a classic car' is included in two dictionaries, according to which it goes back to English oldtimer (КомлЕв 1999: 252, ССИС 2009: 293). In the source language, however, the noun old-timer can refer only to 'a very experienced or long-serving person' (OED). The semantic shift from animacy to inanimacy ('an old person' > 'an old car') might have taken place in the German language, where Oldtimer is a polysemous word having both of the meanings mentioned above. ${ }^{3}$ So we can conclude that in German, this word is a pseudo-Anglicism in its first meaning ('an old object'), and a real Anglicism in its second sense ('an old person'). It is only the former meaning in which the term was transferred into Russian, with the latter being lost in the process of borrowing, thus turning олдтаймер into a pseudo-English loan transmitted to Russian through German mediation.

3.6. The Russian term for 'adhesive transparent tape' is скотч. There is only one dictionary that provides the right etymologization for this lexical innovation in Russian: Scotch (tape) (НСИС 2003: 593, НСИС 2008: 782). This information is confirmed by the editors of the Dictionary of European Anglicisms, who claim that originally it was a trade name that came to be generic in France and began to spread from there (DEA 2001: 270-271). In other Russian lexicographic works, the etymon Scotch is indicated either without any commentary (ШАГАЛОВА 2009: 644, ШАГАЛОВА 2011: 497-498) or, mistakenly, with an explanation of its English homonym scotch 'надрез' (Крысин 2000: 650, Крысин 2009: 238-239, Крысин 2012: 317), an archaic term for 'a cut or score in skin or another surface' (OED). The real source of Russian скотч, the trademark Scotch has undergone a particular kind of metonymic shift, "downgrading" the proper noun to a common noun (cf. FURIASSI 2010: 39). On the basis of dictionary data quoted above, it can be assumed that this semantic change took place in French, and this pseudo-Anglicism as a generic trademark was later transferred from French into Russian.

\section{Conclusion}

It is by no means an exhaustive list of all pseudo-Anglicisms in Russian. Further investigation is needed to reveal more of these lexical items whose number can probably be measured by hundreds rather than tens. In the present paper, only the preliminary results of this research have been presented with special emphasis on the lexicographic registration of the analyzed words in Russian. As it has been

\footnotetext{
${ }^{3}$ https://www.duden.de/rechtschreibung/Oldtimer
} 
shown, pseudo-Anglicisms are usually not described adequately in Russian dictionaries: either no etymological information is given in the entry or non-existing English forms are provided. Even in cases when just the components of pseudoloans are indicated, a new lexicographic marker псевдоанглицизм could help to unambiguously demonstrate the origin of these lexical items in Russian dictionaries, as suggested by Ljubov' Nefedova in a recent study on the lexicographic representation of pseudo-Anglicisms in German (НЕФЕдОвА 2013: 123).

\section{Sources}

CED = Collins English Dictionary. https://www.collinsdictionary.com/dictionary/english. DEA 2001 = Görlach Manfred (ed.): A Dictionary of European Anglicisms. A Usage Dictionary of Anglicisms in Sixteen European Languages. Oxford University Press, 2001.

Merriam-Webster = Dictionary by Merriam-Webster . https://www.merriam-webster.com. OED = Oxford English Dictionary. https://en.oxforddictionaries.com.

ВАСЮКОВА $1999=$ ВАСЮКОВА И. А. Словарь иностранных слов (с грамматическими формами, синонимами, примерами употребления). Москва: «АСТ-Пресс», 1999.

ГРИГОРЕНКО 2009 = ГРИГОРЕнКО О. В. Новые наименования лиц в современном русском языке. Словарные материальл. Воронеж: «Научная книга», 2009.

Дьяков $2010=$ Дьяков А. И. Словарь англицизмов русского языка. Новосибирск: «Новосибирское книжное издательство», 2010. http://anglicismdictionary.dishman.ru.

ИСАЗ 2016 = ХОДЖАГЕЛЬДЫЕВ Б. Д., ШУРУПОВА О. С. Иллюстрированный словарь английских заимствований в русском языке последних лет. Москва: «Флинта», 2016.

КОмЛЕВ 1995 = КомЛЕВ Н. Г. Словарь новых иностранных слов (с переводом, этимологией и толкованием). Москва: «Издательство МГУ», 1995.

КомЛев 1999 = КомЛЕв Н. Г. Словарь иностранных слов. Москва: «Эксмо-Пресс», 1999.

Крысин $2000=$ КРысин Л. П. Толковый словарь иноязычных слов. Москва: «Русский язык», 2000.

Крысин 2009 = Крысин Л. П. 1000 новых иностранных слов. Москва: «АСТ-Пресс», 2009.

Крысин 2012 = Крысин Л. П. Современный словарь иностранных слов. Москва: «АCТ-Пресс», 2012.

НС3-60 = Новые слова и значения. Словарь-справочник по материалам прессы и литературы 60-х годов. Москва: «Советская энциклопедия», 1971.

НС3-90 = Новые слова и значения. Словарь-справочник по материалам прессы и лиmературы 90-х годов XX века. Т. 1-3. Санкт-Петербург: «Дмитрий Буланин», 2009-2014.

НСИС 2003 = ЗАХАРЕНКО Е. Н., КОМАРОВА Л. Н., НЕЧАЕВА И. В. Новый словарь иностранных слов. Москва: «Азбуковник», 2003.

НСИС 2008 = ЗАХАРЕНКО Е. Н., КОМАРОВА Л. Н., НЕчАЕВА И. В. Новый словарь иностранных слов. Изд. 3-е, испр. и доп. Москва: «Азбуковник», 2008.

POC 2012 = Русский орфографический словарь. Изд. 4-е, испр. и доп. Москва: «АСТПресс», 2012. 
СКЛЯРЕВСКАЯ 1998 = СКЛЯРЕВСКАЯ Г. Н. (ред.) Толковый словарь русского языка кониа ХХ века. Языковые изменения. Санкт-Петербург: «Фолио-Пресс», 1998.

СКЛЯРЕВСКАЯ 2006 = СКЛЯРЕВСКАЯ Г. Н. (реД.) ТолКовый словарь русского языка начала XXI века. Актуальная лексика. Москва: «Эксмо», 2006.

СКЛЯРЕВСКАЯ-ВАУЛИНА 2004 = СКЛЯРЕВСКАЯ Г. Н., ВАУЛИНА Е. Ю. Давайте говорить правильно! Новейшие и наиболее распространеннье заимствования в современном русском языке. Санкт-Петербург: СПбГУ, 2004.

ССИС 2002 = Современньй словарь иностранных слов: толкование, словоупотребление, словообразование, этимология. Изд. 3-е, доп. Москва: «Цитадель-трейд», 2002.

ССИС 2009 = ЧЕРКАСОВА М. Н., ЧЕРКАСОВА Л. Н. Современный словарь иностранных слов. Ростов-на-Дону: «Феникс», 2009.

СТС 2001 = КУзНЕцОВ С. А. Современный толковый словарь русского языка. СанктПетербург: «Норинт», 2001.

ШАГАЛОВА 2009 = ШАГАЛОВА Е. Н. СЛоварь новейших иностранных слов (конеи ХХначало ХХІ вв.). Москва: «АСТ», «Астрель», 2009.

ШАГАЛОВА 2011 = ШАГАЛОВА Е. Н. Самый новейший толковый словарь русского язька ХХІ века. Москва: «АСТ», «Астрель», 2011.

ШАГАЛОВА 2017 = ШАГАЛОВА Е. Н. Словарь новейших иностранных слов. Москва: «АCТ-Пресс», 2017.

\section{References}

ANDERSON $2016=$ ANDERSON Matthew: The foreign words that seem like English - but aren't. BBC Culture, 14 October 2016. http://www.bbc.co.uk/culture/story/20161014the-foreign-words-that-seem-like-english-but-arent?ocid=fbcul.

FuRIASSI 2010 = FurIASSI Cristiano: False Anglicisms in Italian. Monza: Polimetrica, 2010. Furiassi-Gottlieb 2015 = Furiassi Cristiano, Gottlieb Henrik (ed.): Pseudo-English . Studies on False Anglicisms in Europe. Berlin-New York: Walter de Gruyter, 2015.

HuMBLEy 2015 = HuMBLEY John: Allogenisms. The major category of "true" false loans. In: Furiassi Cristiano, Gottlieb Henrik (ed.): Pseudo-English. Studies on False Anglicisms in Europe. Berlin-New York: Walter de Gruyter, 2015. 37-52.

ONYSKo 2007 = ONYSKo Alexander: Anglicisms in German. Borrowing, Lexical Productivity, and Written Codeswitching. Berlin-New York: Walter de Gruyter, 2007.

Pulcini 2002 = PulCINI Victoria: Italian. In: GörlaCH Manfred (ed.): English in Europe. Oxford University Press, 2002. 151-167.

Дьяков 2012 = Дьяков А. И. Уровни заимствования англицизмов в русском языке. Известия Южного федерального университета. Филологические науки 2012/2: $113-124$.

МАРИНОВА 2013 = МАРИнОВА Е. В. Теория заимствования в основных понятиях и терминах. Словарь-справочник. Москва: «Флинта», 2013.

НЕФЕДОВА 2013 = НЕФЕДОВА Л. А. Псевдозаимствования в современном немецком языке: проблема презентации в толковом словаре. Филологические науки. Вопросы теории и практики. № 1. Тамбов: «Грамота», 2013. 121-123. 